\title{
Potensi Pasar Rakyat di Surabaya Barat sebagai Contoh Pasar Bebas Kantong Plastik
}

\author{
Krisna Andrian Bimantara ${ }^{\mathrm{a}^{*}}$ dan Nita Citrasari ${ }^{\mathrm{a}}$ \\ ${ }^{a}$ Program Studi Teknik Lingkungan, Fakultas Sains dan Teknologi, Universitas Airlangga, Surabaya, Indonesia 60115 \\ Corresponding Author: krisna.andrian.bimantara-2018@fst.unair.ac.id \\ DOI: https://dx.doi.org/10.20961/equilibrium.v5i2.58472
}

Article History

Received: 15-11-2021, Accepted: 04-12-2021, Published: 13-01-2022

\section{Kata kunci:}

Bangunan pasar, Kantong plastic,

Keramaian pasar, Pasar rakyat, Surabaya Barat

\section{Keywords:}

Folk market, Market building, Market crowds, Plastic bag, West Surabaya

\begin{abstract}
ABSTRAK. Surabaya Barat memiliki pasar rakyat yaitu Pasar Lakarsantri, Asemrowo, Balongsari, Manukan Kulon, Banjarsugihan, Simo, dan Simo Mulyo yang berpotensi menyumbangkan timbulan sampah plastik berupa kantong plastik. Disisi lain, timbulan sampah plastik di pasar Kota Surabaya telah mencapai 20 ton/hari. Himbauan terkait pembatasan penggunaan kantong plastik sebenarnya telah diatur dalam Peraturan Daerah Kota Surabaya Nomor 1 tahun 2019 namun belum diketahui oleh setiap pengelola, pembeli, dan pedagang di pasar rakyat Kota Surabaya sehingga perlu Program Pasar Rakyat Bebas Kantong Plastik. Namun, aspek bangunan dan keramaian pasar juga perlu dipertimbangkan. Oleh karena itu, penelitian ini bertujuan untuk mengetahui aspek bangunan dan keramaian pasar rakyat di area Surabaya Barat dalam mendukung Program Pasar Rakyat Bebas Kantong Plastik. Metode yang digunakan dalam penelitian ini yaitu metode obeservasi lapangan kemudian dianalisis menggunakan deskriptif kualitatif. Hasil penelitian ini menunjukkan bahwa pasar rakyat di area Surabaya Barat dengan dominasi bangunan permanen serta tingkat keramaian pasar cukup ramai sampai ramai ditetapkan sebagai pasar rakyat yang berpotensi mendukung Program Pasar Rakyat Bebas Kantong Plastik karena mampu melindungi barang dagangan pedagang dan belanjaan pembeli ketika waktu hujan tiba, menciptakan kenyamanan terhadap pembeli pasar untuk berbelanja, serta memudahkan pengawasan dan penertiban. Pasar rakyat tersebut meliputi Pasar Balongsari, Banjarsugihan, dan Simo Mulyo.
\end{abstract}

\begin{abstract}
West Surabaya has folk markets, namely Lakarsantri, Asemrowo, Balongsari, Manukan Kulon, Banjarsugihan, Simo, and Simo Mulyo which have potential to contribute generation of plastic waste in the form of plastic bags. Plastic waste in the Surabaya market has reached 20 tons/day. The call for restrictions on the use of plastic bags has actually been regulated in Peraturan Daerah Kota Surabaya Nomor 1 Tahun 2019 but has not been known by managers, buyers, and traders so that a Plastic Bag Free Traditional Market is needed. However, the market buildings and crowds also need to be considered. This study aims to determine the building and the crowds of the folk markets in the West Surabaya area in supporting the program. The Method used is field observation and qualitative descriptive analysis. The results indicate the dominance of permanent buildings and the level of market crowds from being quite busy to crowded is designated as a folk market that has the potential to support the program because it can protect the merchandise of traders and buyers' purchases when it rains, create convenience for market buyers to shop, as well as facilitate supervision and control. Folk markets include Balongsari, Banjarsugihan, and Simo Mulyo.
\end{abstract}

\section{PENDAHULUAN}

Surabaya merupakan kota di Indonesia yang terletak di Provinis Jawa Timur dengan salah satu kegiatan utama berupa perdagangan. Surabaya sendiri terbagi menjadi lima wilayah yaitu pusat, utara, timur, selatan, dan barat [1]. Dalam bidang perdagangan, Surabaya memiliki tujuh pasar rakyat dibawah pengelolaan PD Pasar Surya yakni Lakarsantri, Asemrowo, Balongsari, Manukan Kulon, Banjarsugihan, Simo, dan Simo Mulyo [2]. Pasar rakyat di Surabaya Barat telah diatur dalam Peraturan daerah Kota Surabaya Nomor 1 Tahun 2015 tentang Pengelolaan dan Pemberdayaan Pasar Rakyat yang salah satu tujuannya untuk mewujudkan pasar rakyat yang bersih, aman, dan nyaman [3]. Namun, berdasarkan observasi lapangan pasar rakyat di Surabaya Barat masih menghasilkan sampah sebagai salah satu penyebab kondisi pasar rakyat yang kumuh, semrawut, becek, bau, dan sumpek [4]. Hasil observasi lapangan menunjukkan jika pasar rakyat di Surabaya Barat di dominasi oleh sampah kantong plastik. Timbulan sampah di pasar rakyat Kota Surabaya telah mencapai 452 ton/hari yang mana sampah plastik merupakan sampah terbanyak kedua setelah sampah sayuran dan makanan. Timbulan sampah plastik sendiri 
mencapai 20 ton/hari atau 4,49\% dari total timbulan sampah pasar rakyat di Surabaya [5]. Disisi lain, sampah kantong plastik sebanyak 300 juta lembar ditemukan dalam timbulan sampah pasar rakyat Kota Bandung dengan kata lain tingginya sampah plastik di pasar rakyat di Surabaya dikhawatirkan keberadaan sampah kantong plastik di pasar rakyat Surabaya Barat juga melimpah [6].

Pemerintah Kota Surabaya sendiri telah berusaha berkontibusi untuk menekan sampah kantong plastik di pasar rakyat dengan membatasi penggunaannya. Usaha tersebut tercerminkan dengan adanya Peraturan Daerah Kota Surabaya Nomor 1 Tahun 2019 tentang Perubahan atas Peraturan Daerah Kota Surabaya Nomor 5 Tahun 2014 tentang Pengelolaan Sampah dan Kebersihan di Kota Surabaya yang dilanjutkan dengan menerbitkan Surat Edaran Wali Kota Surabaya Nomor 660.1/7953/463.7.12/2019 perihal Himbauan Pelarangan Penggunaan Kantong Plastik Sekali Pakai [7,8]. Salah satu target dari surat edaran tersebut yaitu pengelola pasar se-Kota Surabaya namun pada kenyataannya pengelola pasar rakyat di Surabaya Barat banyak yang masih belum mengetahui berdasarkan hasil observasi lapangan. Tidak hanya itu pedagang dan pembeli pada pasar rakyat di Surabaya Barat juga masih banyak yang belum mengetahui adanya kebijakan tersebut. Oleh karena itu, diperlukan Program Dukung Pasar Rakyat Bebas Kantong Plastik di Surabaya Barat sebagai bentuk usaha nyata dalam pengurangan sampah kantong plastik. Pelarangan penggunaan kantong plastik artinya terdapat alternatif pengganti untuk pedagang dan pembeli membungkus barang belanjaanya. Alternatif pengganti kantong plastik dapat berupa rajutan akar, daun, tas kain, serta kantong kertas namun keempatnya memiliki kelemahan yakni tidak tahan air [9,10,11, 12]. Berdasarkan kelemahan tersebut, aspek bangunan pasar perlu dipertimbangkan guna melindungi barang belanjaan pembali apabila hujan yang secara tidak langsung dapat menciptakan rasa nyaman saat berbelanja [12,13]. Selain aspek bangunan pasar, aspek keramaian pasar juga perlu dipertimbangkan mengingat pasar yang tidak terlalu ramai akan memudahkan pengelola pasar dalam pengawasan dan pengaturan [14]. Namun, pasar rakyat yang ramai juga mengindikasikan pasar rakyat tersebut berhasil dalam aktivitas jual beli [15]. Berdasarkan hasil observasi di lapangan, pasar rakyat di Surabaya Barat memiliki bangunan dan keramaian pasar yang beranekaragam sehingga perlu adanya penilaian potensi yang ditinjau dari aspek bangunan pasar, keramaian, pasar, dan kedua aspek tersebut. Pasar rakyat di Surabaya Barat yang memiliki potensi pada kedua aspek tersebut merupakan pasar yang berpotensi untuk mendukung Program Dukung Pasar Rakyat Bebas Kantong Plastik di Surabaya Barat.

\section{METODE PENELITIAN}

Metode dalam penelitian ini yaitu observasi lapangan yang dilakukan dengan mendatangi secara langsung ketujuh pasar rakyat di Surabaya Barat. Data yang diambil dan didokumentasikan meliputi data bangunan yang terdiri dari jenis tempat dagang pedagang (kios, los, atau tenda), kelengkapan struktur bangunan (atap, dinding, lantai, dan pintu), serta jenis bahan penyusun stuktur bangunan (kayu, bambu, batu, bata, atau beton). Selain data bangunan, data keramaian pasar juga diambil pada jam puncak keramaian yang meliputi titik aktivitas jual beli, jumlah pedagang, dan jumlah pembeli. Kedua data kemudian di analisis secara deskriptif kualitatif untuk mengklasifikasikan jenis bangunan dan keramaian pasar rakyat di Surabaya Barat berdasarkan tinjauan pustaka pendukung. Terakhir, hasil klasifikasi jenis bangunan dan keramaian pasar rakyat di Surabaya Barat dinilai potensinya dengan menggunakan Metode Multi Attribute Utility Theory (MAUT). Metode MAUT memudahkan untuk perangkingan pasar rakyat di Surabaya Barat dengan pemberian nilai dan bobot [16].

\section{HASIL DAN PEMBAHASAN}

\subsection{Studi Bangunan Pasar Rakyat di Surabaya Barat}

Data observasi lapangan terhadap ketujuh pasar rakyat di Surabaya Barat kemudian didekatkan dengan pustaka yang membahas mengenai jenis bangunan dengan klasifikasi bangunan meliputi permanen, semipermanen, dan nonpermanen. Berdasarkan tinjauan pustaka didapatkan definisi ketiga jenis bangunan tersebut yakni bangunan permanen adalah bangunan yang identik dengan kios dan memiliki pembatas antarkios berupa tembok, atap, serta pintu. Bangunan semipermanen adalah bangunan yang identik dengan los, tidak memiliki pembatas antar los dan pintu, bahan penyusun meja terdiri dari kayu, beton, atau keramik, serta memiliki atap. Bangunan nonpermanen adalah bangunan yang identik dengan sementara dengan bahan penyusun bangunan yakni kayu, bambu, terpal berbentuk tenda, atau ketiganya $[17,18,19,20,21,22]$. Berdasarkan data bangunan hasil observasi lapangan yang kemudian didekatkan dengan ketiga definisi jenis bangunan pasar tersebut didapatkan klasifikasi dan dominasi jenis bangunan setiap pasar rakyat di Surabaya Barat yang dapat dilihat pada Tabel 1. 
Table 1. Klasifikasi jenis bangunan pasar rakyat di Surabaya Barat dibawah pengelolaan PD pasar surya

\begin{tabular}{cllcccc}
\hline \multirow{2}{*}{ No. } & \multirow{2}{*}{ Nama Pasar } & \multicolumn{1}{c}{ Alamat } & \multicolumn{2}{c}{$\begin{array}{c}\text { Klasifikasi Ketersediaan } \\
\text { Bangunan Pasar }\end{array}$} & \multicolumn{2}{c}{$\begin{array}{c}\text { Klasifikasi } \\
\text { Dominasi } \\
\text { Bangunan Pasar }\end{array}$} \\
\cline { 3 - 6 } & & P & SP & NP & Semipermanen \\
\hline 1. & Lakarsantri & Jl. Lakarsantri & $\checkmark$ & $\checkmark$ & $\checkmark$ & Semipermanen \\
2. & Asemrowo & Jl. Asemrowo Makam & $\checkmark$ & $\checkmark$ & $\checkmark$ & Permanen \\
3. & Balongsari & Jl. Balongsari & $\checkmark$ & $\checkmark$ & $\checkmark$ & Semipermanen \\
4. & Manukan Kulon & Jl. Raya Manukan Lor & $\checkmark$ & $\checkmark$ & $\checkmark$ & Permanen \\
5. & Banjarsugihan & Jl. Banjarsugihan & $\checkmark$ & $\checkmark$ & $\checkmark$ & Semipermanen \\
6. & Simo & Jl. Simo & $\checkmark$ & $\checkmark$ & $\checkmark$ & Permanen \\
7. & Simo Mulyo & Jl. Simo Mulyo Ngesong & $\checkmark$ & $\checkmark$ & $\checkmark$ &
\end{tabular}

Keterangan: $\checkmark$ ada

\subsection{Studi Keramaian Pasar Rakyat di Surabaya Barat}

Tinjauan terhadap beberapa pustaka yang membahas keramaian suatu tempat dilakukan untuk mengetahui klasifikasi tingkat keramaian pasar beserta kriterianya dengan hasil yang dapat dilihat pada Tabel 2 [24,25,26].

Tabel 2. Klasifikasi tingkat keramaian pasar rakyat berdasarkan tinjauan terhadap beberapa pustaka

\begin{tabular}{|c|c|c|c|c|}
\hline No. & $\begin{array}{l}\text { Klasifikasi } \\
\text { Keramaian }\end{array}$ & Titik Aktivitas Jual Beli & $\begin{array}{c}\text { Jumlah Pedagang } \\
\text { (Orang) }\end{array}$ & $\begin{array}{c}\text { Jumlah Pembeli } \\
\text { pada Jam Puncak } \\
\text { Keramaian Pasar } \\
\text { (Orang) }\end{array}$ \\
\hline 1. & Sangat Sepi & Hanya di gedung utama & $<40$ & $<15$ \\
\hline 2. & Sepi & Hanya di gedung utama & $40-84$ & $15-29$ \\
\hline 3. & Cukup Ramai & Gedung utama dan sekitarnya & $85-129$ & $30-44$ \\
\hline 4. & Ramai & $\begin{array}{l}\text { Gedung utama dan sekitarnya serta } \\
\text { jalan sekeliling gedung utama }\end{array}$ & $130-175$ & $45-60$ \\
\hline 5. & Sangat Ramai & $\begin{array}{l}\text { Gedung utama dan sekitarnya, jalan } \\
\text { sekitarnya, dan gang-gang } \\
\text { perkampungan }\end{array}$ & $>175$ & $>60$ \\
\hline
\end{tabular}

Sumber: Sari et al. (2018) ; Nurhalimah et al. (2020) ; Rizal et al. (2017)

Data keramaian pasar diklasifikasikan dengan mengacu pada Tabel 2 sehingga didapatkan klasifikasi keramaian setiap pasar rakyat di Surabaya Barat yang dapat dilihat pada Tabel 3.

Tabel 3. Klasifikasi tingkat keramaian pasar rakyat di Surabaya Barat dibawah pengelolaan PD Pasar Surya

\begin{tabular}{|c|c|c|c|c|c|}
\hline No. & Nama Pasar & Titik Aktivitas Jual Beli & $\begin{array}{c}\text { Jumlah } \\
\text { Pedagang } \\
\text { (Orang) }\end{array}$ & $\begin{array}{l}\text { Jumlah } \\
\text { Pembeli } \\
\text { (Orang) }\end{array}$ & $\begin{array}{l}\text { Klasifikasi } \\
\text { Keramaian }\end{array}$ \\
\hline 1. & Lakarsantri & Gedung utama dan sekitarnya & 53 & 41 & Cukup Ramai \\
\hline 2. & Asemrowo & Hanya di gedung utama & 150 & 48 & Ramai \\
\hline 3. & Balongsari & Hanya di gedung utama & 179 & 54 & Ramai \\
\hline 4. & $\begin{array}{l}\text { Manukan } \\
\text { Kulon }\end{array}$ & Hanya di gedung utama & 93 & 27 & Sepi \\
\hline 5. & Banjarsugihan & Gedung utama dan sekitarnya & 74 & 39 & Cukup Ramai \\
\hline 6. & Simo & Hanya di gedung utama & 103 & 44 & Cukup Ramai \\
\hline 7. & Simo Mulyo & Gedung utama dan sekitarnya & 123 & 37 & Cukup Ramai \\
\hline
\end{tabular}

3.3 Penilaian Potensi Pasar Rakyat Berdasarkan Aspek Bangunan dan Keramaian Pasar untuk Mendukung Program Dukung Pasar Rakyat Bebas Kantong Plastik di Surabaya Barat Menggunakan Metode MAUT

Penilaian potensi pasar rakyat di Surabaya Barat berdasarkan kedua aspek menggunakan Metode Maut dilakukan karena metode ini dapat memudahkan untuk membantu menilai potensi berdasarkan ranking masing- 
masing pasar. Tahapan dalam penilaian potensi menggunakan Metode Maut diantaranya penentuan kriteria masing-masing aspek, pemberian nilai masing-masing kriteria, melakukan konfigurasi nilai utility, pemberian bobot, perhitungan nilai akhir, dan melakukan perangkingan [27].

Tabel 4. Aspek, kriteria, nilai, dan bobot yang digunakan dalam penilaian potensi pasar rakyat untuk mendukung Program Dukung Pasar Rakyat Bebas Kantong Plastik di Surabaya Barat Menggunakan Metode MAUT

\begin{tabular}{|c|c|c|c|c|c|}
\hline No. & Aspek & Kriteria & $\begin{array}{c}\text { Nilai } \\
\text { Kriteria }\end{array}$ & Nilai Utility & Bobot \\
\hline \multirow{5}{*}{1.} & & Permanen & 3 & & \\
\hline & Bangunan & Semipermanen & 2 & 0,3 & 75 \\
\hline & & Nonpermanen & 1 & & \\
\hline & & Sangat Ramai & 2 & & \\
\hline & & Ramai & 5 & & \\
\hline \multirow[t]{3}{*}{2.} & Keramaian & Cukup Ramai & 4 & 0,2 & 25 \\
\hline & & Sepi & 3 & & \\
\hline & & Sangat Sepi & 1 & & \\
\hline
\end{tabular}

Keterangan: Nilai utility didapatkan dari perbandingan 1 dengan nilai terbesar dari nilai kriteria sedangkan bobot didapatkan dari pertimbangan pengaruh antara kedua aspek terhadap potensi

Tabel 5. Nilai akhir dan ranking potensi masing-masing pasar berdasarkan aspek bangunan dan keramaian menggunakan Metode MAUT

\begin{tabular}{clcccc}
\hline No. & Nama Pasar & Bangunan & Keramaian & Total Nilai & Rangking \\
\hline 1. & Lakarsantri & 0 & 12,5 & 12,5 & 6 \\
2. & Asemrowo & 0 & 25 & 25 & 4 \\
3. & Balongsari & 75 & 25 & 100 & 1 \\
4. & Manukan & 0 & 0 & 0 & 7 \\
5. & Kulon & & & & 2 \\
6. & Simjarsugihan & 75 & 12,5 & 87,5 & 5 \\
7. & Simo Mulyo & 75 & 12,5 & 12,5 & 3 \\
\hline Keterangan: Nilai akhir didatka
\end{tabular}

\section{KESIMPULAN}

Berdasarkan hasil dan pembahasan dalam penelitian ini dapat ditarik kesimpulan dan saran, yaitu:

1. Pasar rakyat yang mempunyai potensi mendukung Program Dukung Pasar Rakyat Bebas Kantong Plastik di Surabaya Barat berdasarkan aspek bangunan adalah Pasar Balongsari, Banjarsugihan, dan Simo Mulyo.

2. Pasar rakyat yang mempunyai potensi mendukung Program Dukung Pasar Rakyat Bebas Kantong Plastik di Surabaya Barat berdasarkan aspek keramaian adalah Pasar Lakarsantri, Asemrowo, Balongsari, Banjarsugihan, Simo, dan Simo Mulyo.

3. Pasar rakyat yang mempunyai potensi sebagai pasar rakyat percontohan bebas kantong plastik di Surabaya Barat berdasarkan aspek bangunan dan keramaian adalah Balongsari, Banjarsugihan, dan Simo Mulyo.

4. Pemilihan satu pasar rakyat percontohan bebas kantong plastik di Surabaya Barat harus disertai dengan parameter kunci misalnya kesiapan dan dukungan pengelola.

\section{UCAPAN TERIMA KASIH}

Terima kasih kepada Dinas Lingkungan Hidup Kota Surabaya ; PD Pasar Surya ; Ibu Nita Citrasari S.Si., M.T. ; serta seluruh anggota Tim Limbah Padat, Program Studi Teknik Lingkungan, Departemen Biologi Fakultas Sains dan Teknologi, Univesitas Airlangga yang telah membantu selama penelitian ini berlangsung.

\section{REFERENSI}

[1] Pemerintah Kota Surabaya Dinas Lingkungan Hidup, "Profil Keanekaragaman Hayati \& Ekosistem Kota Surabaya 2018,” in Dinas Lingkungan Hidup Pemerintah Kota Surabaya, Surabaya.

[2] Badan Pusat Statistik, "Surabaya dalam Angka 2021," in Badan Pusat Statistik Kota Surabaya, Surabaya. 
[3] Peraturan daerah Kota Surabaya Nomor 1 Tahun 2015 tentang Pengelolaan dan Pemberdayaan Pasar Rakyat.

[4] L. D. Sawitri, "Kepuasan Pelanggan terhadap Administrasi Lingkungan Ditinjau dari Kebersihan Pasar Tradisional di Kabupaten Sidoarjo” in Jurnal Ilmiah Administrasi Bisnis dan Inovasi., Surabaya, 2017, pp. 135-153.

[5] I. Indawati, “Identifikasi Timbulan dan Emisi Gas Rumah Kaca Sampah Pasar di Kota Surabaya” in Jurnal Matriks Teknik Sipil., 2020, pp. 454-461.

[6] Ma'arup

[7] Peraturan Daerah Kota Surabaya Nomor 1 Tahun 2019 tentang Perubahan atas Peraturan Daerah Kota Surabaya Nomor 5 Tahun 2014 tentang Pengelolaan Sampah dan Kebersihan di Kota Surabaya

[8] Surat Edaran Wali Kota Surabaya Nomor 660.1/7953/463.7.12/2019 perihal Himbauan Pelarangan Penggunaan Kantong Plastik Sekali Pakai

[9] H.P. Putra dan Y. Yuriandala, "Studi Pemanfaatan Sampah Plastik Menjadi Produk dan Jasa Kreatif” in Jurnal Sains dan Teknologi Lingkungan., Yogyakarta, 2010, pp. 21-31.

[10] P.G.R.A. Suwendra dan A. Suharta, “Alternatif Pengganti Plastik Sekali Pakai pada Peraturan Gubernur Bali Nomor 97 Tahun 2018” Skripsi, Program Kekhususan Hukum Pemerintahan., Fakultas Hukum., Universitas Udayana. 2019.

[11] N. Nasrun., E. Kurniawan., dan I. Sari, "Studi Awal Produk Bahan Bakar dari Proses Pirolisis Kantong Plastik Bekas” in Jurnal Teknologi Kimia UNIMAL., Aceh Utara, 2017, pp. 30-44.

[12] A. Muliantara., N. A. S. ER., dan I. M. Widiartha, "Perancangan Alat Ukur Ketinggian Curah Hujan Otomatis Berbasis Mikrokontroler” in Jurnal Ilmiah Ilmu Komputer Universitas Udayana., Bali, 2015, pp. 31-37.

[13] C. R. Maria., E. Pandelaki., dan A. Suprapti, "Prisip-prinsip taman ramah anak berdasarkan sudut pandang pengguna” in Jurnal Pembangunan Wilayah dan Perencanaan Partisipatif., Surakarta, 2021, pp 291-310.

[14] M. N. Fajri, "Kriteria Perancangan Ruang Publik yang Aman Bagi Anak-Anak di Kawasan Simpang Lima Semarang” Tugas Akhir, Jurusan Perencanaan Wilayah dan Kota., Fakultas Teknik., Universitas Diponegoro, 2019.

[15] A. P. Anggreini, "Revitalisasi Pasar Tradisional dalam Pemberdayaan Pedagang Pasar Panjerejo Kecamatan Rejotangan, Kabupaten Tulungagung” Skripsi, Program Studi Administrasi Negara., Fakultas Ilmu Sosial dan Ilmu Politik., Universitas Airlangga. 2018.

[16] A. Faruq, "Penerapa Metode Multi Attribute Utility Theory (MAUT) untuk Pemilihan Sekolah Menegah atas di Kecamatan Balung Berbasis Web” Skripsi, Departemen Teknik Informatika, Fakultas Teknik, Universitas Muhammadiyah Jember, 2021.

[17] N. F. Agus, "Pengelolaan Pasar Induk Pagar Dewa Kota Bengkulu” in Jurnal Penelitian Sosial dan Politik., Bengkulu, 2018, pp 27-31.

[18] J. Bosawer., P. H. Gosal., dan E. D. Takumansang, “Tingkat Pelayanan Pasar Remu dan Pasar Boswesen di Kota Sorong” in Spasial : Perencanaan Wilayah dan Kotaí., 2016, pp 20-26.

[19] I. Aliyah, "Pemahaman Konseptual Pasar Tradisional di Perkotaan” in Jurnal Pariwisata dan Budaya., 2017, pp 1-16.

[20] R. A. Apsari, “Hubungan Kualitas Permukiman dan Fasilitas Pelayanan Kesehatan terhadap Derajat Kesehatan Masyarakat berdasarkan Aplikasi Penginderaan Jauh dan Sistem Informasi Geografi Daerah Kecamatan Pasar Kliwon” Skripsi, Fakultas Geografi, Universitas Muhammadiyah Surakarta, 2013.

[21] M. Masyhuri dan S. W. Utomo, “Analisis Dampak Keberadaan Pasar Modern terhadap Pasar Tradisional Sleko di Kota Madiun” in Jurnal Akutansi dan Pendidikan., 2017, pp 59-72.

[22] R. K. Ramadhani, "Konsep Penataan Pasar Mebel di Surakarta melalui Pengolahan Tapak, Pengolahan Massa, dan Desain Tanggap Kebakaran” in Jurnal Ilmiah Mahasiswa Arsitektur., 2021, pp 306-307.

[23] Y. Lustiadi, "Efektivitas Kebijakan Pengelolaan Pasar Tradisional di Kabupaten Ogan Komering Ulu” in Jurnal Kebijakan \& pelayanan Publik.., 2019, pp 74-82.

[24] A. R. Sari dan H. S. Rini, "Hari Pasaran Lagi dan Tidakan Sosial Ekonomi Masyarakat di Pasar Tradisional” in Solidarity., 2018, pp 365-377.

[25] D. Nurhalimah dan D. W. Astuti, “Analisis Hubungan Konfigurasi Ruang dengan Penyebaran Pengunjung Pasar Klewer Menggunakan Spae Syntax” in SINEKTIKA Junral Arsitektur., 2020, pp 13-20.

[26] R. M. Rizal., N. R. Alhamidi., F. Hermawan., dan Ismiyati, "Karakteristik Lokasi Pasar Tradisional dan Dampak Operasionalnya: Studi Kasus Kota Semarang” in Jurnal Riptek., Semarang, 2018, pp 71-82. 
[27] N. Hadinata, "Implementasi Metode Multi Attribute Utility Theory (MAUT) pada Sistem Pendukung Keputusan dalam Menentukan Penerima Kredit” in Jurnal SISFOKOM., Palembang, 2018, pp 87-92. 